\title{
Concessions in Albania and Macedonia in Comparative Law (Interdisciplinary Studies)
}

\author{
PhD (Uni Graz) Mag. lur (Uni Graz) Endri Papajorgji
}

Karl Franzens Universität Graz ; Universiteti Luarasi endripapajorgji@hotmail.com

\section{Doi:10.5901/ajis.2014.v3n3p467}

\begin{abstract}
The changes of political and economic system in the late 80's in Macedonia and early 90's in Albania required a broader reform of the entire legal system by creating a functioning market based in the rules of free market and competition and the privatization of state enterprises. Roggemman (Roggemann 1993) describes the transformation as a transformation from state institutions in Albania - or selfmanaged enterprises in Macedonia, into western commercial companies such as JSC or limited partnership. In this sense the concession-process was one of the main pillars of the privatization process in Albania and Macedonia that built the foundation of free market economy. For more than 40 years, the Albanian and Macedonian citizens were faced with the communist ideology as the basis of state government regulation. This ideology stated that all citizens had contributed the same way and in the same extent during socialism for the construction of state and social property. In this context, the concession - process was accompanied by the deficiency of accurate economic statistics, concession strategies, foreign investors, a bad policy implementation as well as delays in the framework of immedialy needed reforms (Åslund 2013). The main objective of this article is to analyze the concession - process in Albania and Macedonia in comparative law, keeping in mind their EU-integration.
\end{abstract}

Keywords: Concessions, Economy, law, Albania, Macedonia.

\section{Introduction}

Albania and Macedonia are two candidates for EU Membership. Although both states followed the communist pattern (had a different approach as a consequence of the central planned economy in Albania and selfadministration of workers in Macedonia), the transition process in both countries in the beginning of the 90's was followed by a fundamental change not only in the whole economic system but of the whole society in both states. But before the transition, with the coming of Communism, both states followed the Soviet pattern: nationalization of major enterprises, state direction of investment and production through a series of Five-Year Plans, emphasis on heavy industry and collectivization of agriculture. After the 50's Macedonia as part of Yugoslavia followed its own system with the selfadministration of workers a mix of central planning- and free market economy and Albania continued with the central planning until 1990.

The problem with transition in both states was closely connected with the extent and form of implementation of economic reforms and especially privatization, because some enterprises had at least to be transformed, others restructured and others had to be completely liquidated. Another problem with transition was closely connected with two questions: the question of economics and the question of politics. In fact, it can be argued that what has happened in Albania and Macedonia, but also in all post-communist Balkan states and the new countries that have emerged since 1989, is historically unique (Papajorgji 2013).

The transformation process in South East Europe was unprecedented, significant effect of the legal-economic transformation process and necessary precondition for the introduction of a market economy (Åslund 2013). Privatization, political democratization and the development of legislation were the core of this transformation (Roggemman 1993). In incredible ten years, more than 150,000 medium and large enterprises, hundreds of thousands of small businesses and millions of apartments and houses in the countries of Southeast Europe have been privatized (Åslund 2013). These figures show the importance of this process in the post-communist states.

As regards to the effect of transition on the economic system of these two countries, the transformation did not result in stabilization. Rather, it came to a "cross-layer" between central government managed or self-management into an autonomy-based company, which did not permit the full development into the market economy.

No other measure has had such a serious effect on the creation of new social orders.

In this sense Albania and Macedonia have tried to provide goods or services to their citizens that could, in some 
form, be provided by the private sector. The most common method, that we stated before is privatisation, or outright sale or transfer of ownership of the relevant assets to one or more private parties. A second, however, is concession. ${ }^{1}$ Concessions are often viewed as a substitute for privatisation when the latter is not feasible for political or legal reasons. This paper deals with concessions and the development of this process in both countries analysed in a legal and economical point of view.

\section{Concession Process in Albania and Macedonia in Comparative Law}

As I stated in the introduction, concession can be defined as another form of privatization. The granting of a concession is primarily used to attract foreign investors and to induce them to invest.

The first laws, that contained regulations about concession, were the Macedonian "Concession Law of 7.7.1993"2 and the Albanian "Law No. 7973 of 26.7.1995 on the concession and the involvement of the private sector in public services and infrastructure". ${ }^{3}$ The main objective of both laws was the creation of a legal framework for the award of public service contracts and public infrastructure to private companies (natural and legal persons) through concession by entering into private-public partnerships. These regulations included two types of concession agreements:

- BOT (Build-Operate-Transfer), in which one or more commercial companies finance a property for a specified time, build, manage for a certain time and then transfer it to to the state. Other forms of the BOT contract are BTO (Build-Transfer-Operate) and BLT (Build-Lease-Transfer).

- The BOOT concession contract (Build-Own-Operate-Transfer) corresponds to the BOT contract, only that a private party is the owner of the project. In a BOO contract (Build-Own-Operate) the trading company has the right to build and administer or take advantage of the object; a transfer to an agency or the government, however, is not provided. ${ }^{4}$

In Albania, Concessions could be granted in the fields of water supply, railway-, air- and water transport, the construction of tunnels and bridges, power generation and supply, in the telecommunications sector, in the field of waste management and industrial zones in Albania. The contract should include the representation and authorized signatories, terms, conditions, specifications for the construction, rules on cases of force majeure, the rights and obligations of the concessionaires and the authorized state body, liability protection and final provisions. In disputes decided the state courts or international arbitration courts.

In Macedonia, the sectors that were eligible for concession, were not explicitly specified by law. The Concession Law of 1993, decribed only the method and conditions for the use of public property, the conditions that had to be met by the concessionaire, the start date and the duration of the concession, as well as rules on the early termination of contract, quantity and manner of payment of the license fee; in addition the licensed areas were determined, the possibility of concession termination in public interest, the way of concession acquisition, supervision of the concession activities and the conditions for the improvement and protection of the environment during the performance of the licensed activity.

The concession could be granted like in Albania through a tender sale process. The concession contract had the same content as in Albania. In case of dispute, it was chosen the court that was specified in the concession agreement.

The new Albanian Concession Law of $18.12 .2006^{5}$ abolished the law of 1995. Article 2 paragraph 3 of the new law defined Concession as an agreement between the Contracting Authority and the concessionaire and defined the requirements and conditions for the realization of economic activities. This law defined also the risk taking. The field of application for Concessions was expanded in different sectors, such as education, health, tourism, prison infrastructure and oil supply. The application of Concession procedure would be supervised by the Public Procurement Agency. In addition, the Agency for implementation, evaluation and Concession Agreement, which was incorporated under the guidance of the Ministry of Economy, was established. ${ }^{6}$ The rules about the content of the contract were not changed in comparison to the content of the concession contract based on the law of 1995 and also the Macedonian law of 1993,

\footnotetext{
${ }^{1}$ An accepted definition of a concession is: a grant to a private firm of the right to operate a defined infrastructure service and to receive revenues deriving from it.

2 Zakon za koncesija, SI V RM 1993/42; SI V RM 1999/44; SI V RM 2002/25; SI V RM 2003/24.

${ }^{3}$ Ligj Nr 7973 Mbi koncesionin dhe perfshirjen e sektorit privat ne sherbimet publike dhe infrastrukture, date 26.7.2995, FI Z 1995, Nr 19, 805.

${ }^{4}$ Compare Article 2 paragraph 7 of the Albanian Concession Law with Article 3 of Macedonian Concession Law.

${ }^{5}$ Ligj Nr 9663 Mbi koncesionin, date 18.2.2006, Fl Z 2006, Nr 150, 6075; FI Z 2008, Nr 156, 156; Fl Z 2009, Nr 86, 3775 ; FI Z 2010, Nr $73,3931$.

${ }^{6}$ They were established based on Decision of CoM No 150 of 22.3.2007.
} 
while Concessionaires, Shareholders and Partners were free of regulation within their legal relations.

The new Albanian law no. 125/2013 of 25.04.2013 on Concession and Public-Private Partnership (PPP), ${ }^{7}$ which was in accordance with Directive No. 2004/18/EC of the European Parliament and European Council of 31.3.2004 on the coordination of procedures for granting procurement in the context of public buildings, supplies and services, abolished the Albanian law of 2006 and its amendments and strengthened the role of the Ministry of Finance (Malltezi 2013). Public-Private Partnerships in Albania do not provide any rule about risk taking between parties. In the case of Concession, the concessionaire holds the risk of commercial activities, except when the negative consequences derive as a result of wrong decisions with public contracting partner or public authority. In contrast to that, Article 3 of the law on public procurement, ${ }^{8}$ provides that public procurement is a binding contract with a reward for completion of goods and services between public party and the receiver of obligations and this means that the risk taking for contractual fulfillments will be held by the state procurement authority.

The receivers of procurement are responsible for the obligations undertaken by them. In Concessions, the concessionaire is responsible for the preparation of the project, which requires contractual obligation for its funding, application and fulfillment (Malltezi 2013).

The new Albanian law provided 3 types of Concessions: a. Concession, through which the concessionaire, gives the right of use in the field of material goods, for example, in the field of water supply, natural resources and minerals, $b$. Concessions for the implementation of public works and c. Concessions for granting public services. According to Article 5, Law on Concessions and Public-Private Partnership is not applied on Concessions on construction measures for the construction and management of hydropower stations and power supplies, for which the law of 1996 was valid. This dual system will be abolished within four years from the entry into force of the new law of 2013. Until then, all service contracts and concessions must be completed with the old law and be subject to the new law of 2013. New contracts need to be signed for a maximum term of 35 years (Malltezi 2013).

Until 2007, Macedonia regulated concessions and Public-Private Partnership with particular laws, and indeed specific sectors through economic laws and the law on public procurement. ${ }^{9}$ The new Law on Concessions and PublicPrivate Partnership in $2008^{10}$ facilitated and improved the legal framework for all types of concessions. However, as previously described, specific aspects of economic areas were regulated by different laws, which had priority over the Concession law (Georgievski 2009). As in Albania, this law was drafted in accordance with the EU Directive No 2004/18/EC. This law regulated the contractual partnerships and institutional forms of concession and Public-Private Partnership:

- According to the Macedonian law, a contractual partnership is understood as a partnership based on the contract between the Concessionaire and Contracting Authority, a physical- or legal person, domestic or foreign.

- With an institutional partnership is understood the partnership between the Concessionaire and Contracting Authority, also a physical - or legal person, domestic or foreign, while the object of investment is owned by both parties.

In article 3 of this law, the Concession was defined as giving the right to work for the public interest of the Republic of Macedonia and to have the obligation as a Concessionaire to build, administrate and make use of the object given for Concession and pay for it. As a public Contracting Authority could rather be the Republic of Macedonia or the Municipalities like for ex.: The Municipality of Skopje (Georgievski 2009).

As in the Albanian Law, this law also forecasts three different procedures in giving the concessions: a. The open procedure; b. The restricted procedure; and c. the negotiated procedure, that are in full accordance with the Directive of 2004/18/EC for special cases. The procedures were conducted by a Commission chaired by the responsible Minister or the Head of Municipality or the Head of Municipality of Skopje. The Commission was composed of the Chairman, ViceChairman, and three persons from the Ministry of Finance and other experts. The Commission has to prepare the documents for the procurement procedure and also to conduct the dialogue with the Bidder. After that, the Commission would prepare a report and send it to the Contracting Authority, who would respectively make a decision (Georgievski 2009).

\footnotetext{
${ }^{7}$ Ligj Nr 125/2013 Mbi koncesionin dhe partneritetin publik privat, date 25.4.2013, FI Z 2013, Nr 76, 3271.

${ }^{8}$ Ligj Nr 9643 Mbi prokurimin publik, date 20.11.2006, FI Z 2006, Nr 133, 133; FI Z 2007, Nr 122, 3427; FI Z 2007, Nr 184, 5796; FI Z

2009, Nr 153, 6900.

${ }^{9}$ Zakon za javni nabavki, SI V RM 2007/136.

10 Zakon za koncesii i drugi vidovi na javno privatno partnersvo, SI V RM 2008/7; SI V RM 2008/139; SI V RM 2009/64; SI V RM 2010/52; SI V RM 2012/6.
} 
The new Macedonian Law of Concession and the Partnership between the Public and Private sector entered into force on 11.01.2012. ${ }^{11}$ For the PPP, are applied the same rules defined in the Law of 2008, until the New Concession Commission was established. ${ }^{12}$ This law applies for all the public goods and PPP contracts. It is based on the principles of equity, transparency, proportionality, protection of environment and the principle of efficiency (Article 2).

The new Law of 2012 defines the PPP in article 5 as a form of long - term cooperation between the Contracting Authority and the Concessionaire. It also includes the Concession for public work, public services, work contracts and services. As in the Albanian Law of 2013, the establishment of SPC (Special Purpose Company) was forecasted. This law also determines three procedures for assigning a concession. The procedure is conducted by a Commission, which is composed of 15 members, not 5 as of the law of 2008. It is chaired by the responsible Minister, the Head of Municipality, or the Head of Skopje Municipality and 13 others experts from the Ministry of Economy and Finance. The competences of this Commission include the data processing of the Procurement Documentation, definition of the concession-giving criteria, the requirements for the participants and the preparation of the final evaluation report. The members of the commission are elected for a 4 year mandate. The responsible organ for PPP is the Ministry of Economy. The contracts are signed as in Albania for a maximum term of 35 years.

\section{Conclusions}

As we analysed in this paper, the concession - process, just like privatization in both countries was faced with many challenges. After the fall of the communist regime, the Albanian and Macedonian states were nearly bankrupt. In addition the old inherited technology, the lack of investment (savings were in short supply) and especially competition from abroad (imported products) made it hard for state-owned firms to survive and grow in the industrial sector. Most of them changed their activities or ceased operation. These developments, in the first years of transition, reshaped the structure of the Albanian and Macedonian economies in favor of agriculture, trade and service sectors. As if the organizational and procedural problems were not enough, another one was added, that included the lack of government financial resources. The Albanian and Macedonian authorities were totally overwhelmed with the concession - process. This is largely due to the fact that there were no prescribed legal structures and frameworks, that were able to ensure a proper procedure. Neither existed sufficient legal criterias or a commited administration. To evaluate the process in organizational terms, the adequate word in both countries would be "confusion".

In this sense both countries introduced the concession as a new form of attracting foreign investments especially after 2005. This new way of privatization can be described as partly successful, compared to the privatization process which was a total failure. It brought many investors in both countries, but at the same time a lot of bad consequences for both economies, such as the establishment of foreign monopolies especially in the strategic sectors of the economy or the promotion of opportunistic behaviour. In many cases in both countries, the bidder conceded a great deal in the competitive award stage, with the hope or expectation that it was going to recoup these "losses" in renegotiation. After the award the balance of negotiating strength was shifted dramatically in favour of the concessionaire. Both countries for eample could have introduced some steps to minimise the risk of opportunistic behaviour at the award stage, such as: structure the contracts to create as much competition post-award as possible, thus providing the state with more alternative service providers and thereby reducing the bargaining power of the concessionaires.

All in all: Concessions in Albania and Macedonia can serve as a partly positive example of how legal and economic transformation processes should be performed.

\section{References}

Asslund, S. (2013), How capitalism was built - The Transformation of Central and Eastern Europe, Russia, the Caucasus and Central Asia.

Georgievski, T. (2009), The new Macedonian Concessions and Public-Private Partnership Act - A need for Further Improvement? Lex Localis-Journal of local Self-Government $\mathrm{Nr} 2,159$ (160).

Malltezi, A. (2013), Koncesionet në Shqipëri - Nga e drejta private në të drejtën publike.

Papajorgji, E. (2012), E drejta ndërkombëtare tregtare dhe e biznesit. Tiranë.

Papajorgji, E. (2013), Privatisierung von Unternehmen in Albanien und Mazedonien im Rechtsvergleich. Saarbrücken.

Roggemann, S. (1993), Unternehmensumwandlung und Privatisierung in Osteuropa - Gesetzestexte, Analysen, Vertragsgestaltung, p.

11 Zakon za koncesii i drugi vidovi na javno privatno partnersvo, SI V RM 2012/6.

12 The new Commission was established 30 days after the entry in force of this law. It entered on 15.3.2012 in force and all PPPs and Concessions were regulated by this law. 
80.

Zakon za koncesija, SI V RM 1993/42 idF SI V RM 1999/44 idF SI V RM 2002/25 idF SI V RM 2003/24.

Ligj Nr 7973 Mbi koncesionin dhe perfshirjen e sektorit privat ne sherbimet publike dhe infrastrukture, date 26.7.2995, FI Z 1995, Nr 19, 805.

Ligj Nr 9663 Mbi koncesionin, date 18.2.2006, FI Z 2006, Nr 150, 6075; FI Z 2008, Nr 156, 156; FI Z 2009, Nr 86, 3775; FI Z 2010, Nr 73, 3931.

Ligj Nr 125/2013 Mbi koncesionin dhe partneritetin publik privat, date 25.4.2013, FI Z 2013, Nr 76, 3271

Ligj Nr 9643 Mbi prokurimin publik, date 20.11.2006, FI Z 2006, Nr 133, 133; FI Z 2007, Nr 122, 3427; Fl Z 2007, Nr 184, 5796; FI Z 2009, Nr 153, 6900.

Zakon za javni nabavki, SI V RM 2007/136.

Zakon za koncesii i drugi vidovi na javno privatno partnersvo, SI V RM 2008/7 ; SI V RM 2008/139 ; SI V RM 2009/64; SI V RM 2010/52; SI V RM 2012/6.

Zakon za koncesii i drugi vidovi na javno privatno partnersvo, SI V RM 2012/6. 